\title{
MARIÁNSKA HORA V LEVOČI SO ZAMERANÍM NA JEJ MEDZINÁRODNÝ VÝZNAM ${ }^{1}$
}

\author{
Marian Hill in Levoča \\ Focusing on Its International Significance
}

\author{
Ondrej Štefaňak
}

DOI: 10.17846/CL.2021.14.1.158-166

\begin{abstract}
TEFAŇAK, Ondrej. Marian Hill in Levoča Focusing on Its International Significance. Marian devotion is one of the enduring values of the Christian East and West, which are largely associated with the work of Saints Cyril and Methodius in Great Moravia. Sanctuary on Marian Hill in Levoča is undoubtedly one of the most important Marian shrines in Slovakia. Especially in the last four decades, it has received more attention not only in Slovakia, but also in Europe and Worldwide. In 1984 it was declared as Basilica Minor, in 1995 it was visited by Pope John Paul II, in 2005 it was included in the association European Marian Network, in 2009 it obtained a spiritual alliance with the Basilica of Santa Maria Maggiore in Rome, in 2013 it became one among more than three hundred most important shrines Worldwide, which are united every year in the Annual Global Rosary Relay for the sanctification of priests, in 2016 it was included in the Slovakian section of Camino de Santiago and in 2019 it hosted members of the European Marian Network on the occasion of their seventeenth regular session. In the sketched context, the article presents the Marian Hill in Levoča focusing on its growing international significance. It briefly deals with its earlier local history, and in more detail newer - global history.
\end{abstract}

Keywords: Basilica minor, European Marian Network, John Paul II., Levoča, Marian Hill

\section{Úvod}

Medzi trvalé hodnoty krestanského východu i západu, ktoré sa v značnej miere spájajú s pôsobením svätých Cyrila a Metoda na Vel'kej Morave, patrí aj úcta k Božej Matke Panne Márii. Stáročná živá mariánska úcta na Slovensku sa naplno prejavila v tom, že slovenský národ si za svoju nebeskú patrónku vybral práve Sedembolestnú Pannu Máriu. V súčasnosti sa na Slovensku nachádza niekolko mariánskych bazilík a množstvo dalších mariánskych kostolov alebo kaplniek. Tieto mariánske svätyne okrem náboženských funkcií neraz plnia aj funkcie integračné v lokálnej, regionálnej, národnej alebo nadnárodnej škále. Integrujú rôzne národnostné, etnické, sociálne alebo náboženské skupiny. Okolo svätýň s národným alebo nadnárodným významom sa spravidla postupne rozvíja infraštruktúra (cesty, pútnické domy, hotely, reštaurácie alebo obchody), čo napomáha celkovému sociálno-ekonomickému rozvoju daného regiónu (Sugier-Szerega 2004, 360-361).

Svätyňa na Mariánskej hore $\mathrm{v}$ Levoči je bezpochyby jednou z najvýznamnejších mariánskych svätýň na Slovensku. Najmä v posledných štyroch dekádach sa jej dostáva viac pozornosti

Táto práca bola podporovaná Agentúrou na podporu výskumu a vývoja na základe Zmluvy č. APVV-16-0116. 
nielen na Slovensku, ale aj v Európe a vo svete. V roku 1984 jej bol udelený titul Basilica minor, v roku 1995 ju navštívil pápež Ján Pavol II., v roku 2005 bola zaradená do združenia European Marian Network, ktoré spája dvadsat najvýznamnejších mariánskych svätýň starého kontinentu, v roku 2009 nadobudla duchovné spojenectvo s bazilikou Santa Maria Maggiore v Ríme, z čoho pre pútnikov plynú viaceré duchovné privilégiá, v roku 2013 sa v rámci celosvetovej organizácie Worldpriest zaradila medzi najvýznamnejšie svätyne sveta, ktoré sa každoročne na slávnost' Božského srdca Ježišovho spájajú v štafetovej modlitbe ruženca za posvätenie kňazov, v roku 2016 bola zaradená do slovenskej sekcie Camino de Santiago a v roku 2019 hostila členov European Marian Network pri príležitosti ich sedemnásteho riadneho zasadania. Bez nejakej nezdravej hrdosti možno povedat, že o Mariánskej hore v Levoči sa vie nielen na Slovensku, ale aj v Európe a vo svete (Dlugoš 2013).

V načrtnutom kontexte chcem v tomto článku predstavit’ levočskú Mariánsku horu so zameraním na jej rastúci medzinárodný význam. Konkrétne sa budem v krátkosti venovat jej dávnejšej - lokálnej histórii, a podrobnejšie novšej - globálnej histórii. Napokon osobitným spôsobom upriamim pozornost' čitatela na jeden z menej známych aspektov Mariánskej hory, ktorým je jej aktívna prítomnost̉ medzi dvadsiatimi najvýznamnejšími mariánskymi svätyňami Európy. V tejto oblasti pôjde v značnej miere o informácie „z prvej ruky“, nakol'ko som sa osobne zúčastnil na väčšine riadnych zasadaní členov združenia Európskej mariánskej siete.

\section{Dávnejšia - lokálna história Mariánskej hory v Levoči}

Začiatky mariánskej úcty na Slovensku siahajú do jeho najstarších dejín - do čias svätých Cyrila a Metoda, ktorí, hlásajúc Kristovo evanjelium našim predkom, nemohli obíst jeho matku. Korene mariánskeho kultu na Mariánskej hore v Levoči siahajú do 13. storočia a spájajú sa s tatárskymi vpádmi, ked’ ludia utekali do hôr, kde sa nielen ukrývali, ale aj modlili (Chalupecký 2006, 12 13). Levočská mariánska svätyňa síce nemá historicky preskúmané a cirkevne schválené zjavenie Panny Márie, ako napríklad svätyne v Lurdoch alebo vo Fatime, ale to neumenšuje jej význam. Omnoho dôležitejšia je nepretržitá tradícia modlitieb a pútí, ktoré neprestali ani počas reformácie, ani počas komunizmu (Dlugoš 2013, 25-29).

Kaplnka nad Levočou (tzv. prvý kostol) sa spomína už v roku 1247. Vtedy, podla kroniky Lányiho, Levočania postavili na Olivovej hore kaplnku, ktorú zasvätili Duchu Svätému (Jurik 1948, 9-11). Mariánsku úctu, ktorá sa vel’mi rýchlo stala oficiálnym kultom, priniesli do Levoče pravdepodobne františkáni - minoriti na začiatku 14. storočia a podla neho premenovali horu na Mariánsku (Kosová 2016, 269). V načrtnutom kontexte je dôležitou tradícia, že na Mariánskej hore opravovali kaplnku levočskí farári, a to v roku 1311 Henrich a v roku 1322 Šalamon. Je teda zrejmé, že už predtým tam stála kaplnka, ktorá sa tešila zvláštnemu záujmu okolitého obyvatel'stva. Začiatok levočských mariánskych púti by tak siahal najneskôr do začiatku 14. storočia (Chalupecký 2006, 10-12).

V roku 1431 kaplnku spolu s mestom vypálili husiti, preto ju v druhej polovici 15. storočia za farára Servacia Menhardivillu (1466 - 1484) prestavali a zväčšili na malý kostol (tzv. druhý kostol). Z jeho interiérového vybavenia sa zachovala gotická socha Panny Márie odetej slnkom. V roku 1470 sa pri ňom spomína aj pustovňa, pravdepodobne osídlená kartuziánmi, ktorí sa mali o kostol starat počas svojho pôsobenia v Levoči (Kosová 2016, 269). Na okraj možno spomenút, že práve tento druhý kostol na Mariánskej hore je znázornený na lavom krídle hlavného oltára v Bazilike svätého Jakuba v Levoči, ktorý vznikol začiatkom 16. storočia v dielni Majstra Pavla (Kompanyik 1891). 
V čase konfesionálnych bojov v 17. storočí mariánske púte síce pokračovali, kostol však nebol dostatočne udržiavaný a postupne chátral. Opravili ho až v roku 1698 za farára Štefana Ďörfiho Ehrnspergera. V polovici 18. storočia v oprave kostola pokračoval farár Jozef Dulovič, ktorý dal zreštaurovat aj bývalú pustovňu. Napriek spomenutým opravám, pre zlý stavebno-technický stav starý kostol napokon zbúrali a 13. mája 1766 položili základný kameň novej svätyne (tzv. tretí kostol). Tento neskorobarokový kostol však opät prestavali už v roku 1819. Aj táto stavba napokon pre nedostatočnú starostlivost’ schátrala napriek tomu, že si toto pútnické miesto po celý čas udržalo významné postavenie presahujúce hranice mesta a regiónu (Kosová 2016, 270).

Návrh postavit nový a väčší kostol na Mariánskej hore predložil koncom 19. storočia levočský farár Celestín Kompanyik (1886 - 1919). Inšpirovaný mariánskou svätyňou vo francúzskych Lurdoch sa rozhodol pre výstavbu úplne nového, rozsiahleho chrámu. Jeho zámer sa stretol s porozumením a obetavostou veriacich. Základný kameň nového kostola posvätili 2. júla 1903. Stavba prebiehala postupne v závislosti od množstva finančných prostriedkov v rokoch 1903 - 1914. Po mnohých tažkostiach (napr. zrútenie veže v roku 1908) bol tento tzv. štvrtý kostol slávnostne posvätený spišským biskupom Jánom Vojtaššákom 2. júla 1922. Súčasný kostol na Mariánskej hore je dlhý 42,5 metrov a široký 27 metrov. Ide o neogotickú krížovú stavbu, postavenú podla projektu Antona Müllera (Jurik 1948, 30-40).

V medzivojnovom období sa levočská pút stala náboženskou a spoločenskou udalostou čoraz väčšej časti Slovenska. Hlavným celebrantom bol spravidla vtedajší spišský biskup Ján Vojtaššák. Medzi kazatelmi sa však vystriedali aj dalšie významné osobnosti tej doby - napr. Andrej Hlinka v roku 1930, Jozef Čársky v roku 1931, Jozef Špirko v roku 1932 alebo Štefan Barnáš v roku 1933. Púte pokračovali aj po roku 1939 a po skončení druhej svetovej vojny nadobudli mohutný ráz. Zúčastňovali sa na nich pútnici zo všetkých oblastí Slovenska, ba aj zo zahraničia. Pút v roku 1945, na ktorej sa zúčastnilo okolo 100000 pútnikov, mala predovšetkým dakovný charakter za prežitie hrôz vojny. Najmohutnejšia predkomunistická pút bola v roku 1947, na ktorej sa zúčastnilo okolo 130000 pútnikov. Hlavným celebrantom bol spišský biskup Ján Vojtaššák, ktorý na mariánskej hore zasvätil Spišskú diecézu Nepoškvrnenému Srdcu Panny Márie. V tom čase mal vtedajší levočský farár Jozef Vojtas vel'ké plány s prebudovaním a modernizáciou Mariánskej hory, ktoré však po komunistickom prevrate vo februári 1948 ostali nenaplnené (Chalupecký 2006, 26-28).

Ako som vyššie spomenul, púte na Mariánsku horu v Levoči nikdy neprestali, hoci najmä počas komunizmu boli spojené s mnohými tažkostami - a to tak na strane kňazov, ako aj na strane veriacich laikov. Veriaci laici sa často nemali ako dostat' do Levoče a ked’ sa tu dostali, mali z toho nemalé problémy. Kňazi potrebovali štátny súhlas na slúženie svätej omše i na spovedanie. Tento súhlas dostalo maximálne sedem až osem kňazov. Vdaka Bohu, kňazi, ktorí dostali štátny súhlas, vydržali spovedat takmer 48 hodín. Vdaka nim sa mohlo s Bohom zmierit’ niekolko tisíc pútnikov. Tento stav trval až do roku 1989 i napriek tomu, že ordinár Spišskej diecézy vzhladom na množstvo pútnikov žiadal zástupcov štátu o povolenie pre viacerých spovedníkov (Dlugoš 2013, 65-92).

Po páde komunizmu v roku 1989 sa situácia značne zlepšila. Súčasné dianie na Mariánskej hore v Levoči charakterizujú predovšetkým pravidelné i nepravidelné púte a iné pastoračné aktivity. Množstvo veriacich tu prichádza, samozrejme, aj individuálne, nakolko ide o neopakovatelné, tiché, pokojné a modlitbami naplnené miesto. Vrcholom pútnickej sezóny je vždy týždeň, v ktorom sa slávi slávnost’ Navštívenia Panny Márie, na Slovensku pripadajúca na 2. júl. Najmä v sobotu a nedelu tohto týždňa prichádza na Mariánsku horu množstvo veriacich zo všetkých kútov Slovenska i zo zahraničia. Hlavná pút má vždy nejakú ústrednú myšlienku, ktorá súvisí s históriou alebo aktuálnym dianím - napríklad výročie prvej písomnej zmienky, vyhlásenia za Basilicu minor alebo návštevy Jána Pavla II. (Dlugoš - Štefaňak 2014, 79-82). 


\section{Novšia - globálna história Mariánskej hory v Levoči}

Najmä v posledných štyroch dekádach sa Mariánskej hore v Levoči dostáva viac pozornosti nielen na Slovensku, ale aj v Európe a vo svete. Prvým dôležitým medzníkom v rámci jej rastúceho medzinárodného významu bol 26. január 1984, ked’ bol kostolu na Mariánskej hore udelený titul Basilica minor. Vtedajší ordinár Spišskej diecézy Mons. Štefan Garaj požiadal 7. mája 1983 Kongregáciu pre Boží kult a disciplínu sviatostí, aby bol mariánskej svätyni nad mestom Levoča udelený titul baziliky menšej. Od prefekta príslušnej kongregácie, kardinála Jozefa Casoriu, prišla na jar 1984 odpoved’ tohto znenia: „Najvyšší vel'kňaz Ján Pavol II. vyhovel žiadosti a želaniu kňazstva i veriacich [...] a z vlastného popudu poctil titulom a hodnostou baziliky menšej svätyňu kostola na temene Mariánskej hory nad mestom Levoča, zasvätenú tajomstvu Navštívenia preblahoslavenej Panny Márie.“ Tento dekrét bol napriek prekážkam zo strany vtedajšej štátnej moci slávnostne prečítaný počas hlavnej púte na Mariánskej hore 8. júla 1984 (Dlugoš 2015, 91-98).

Mimoriadne dôležitým medzníkom v procese „globalizácie“ Mariánskej hory v Levoči bol 3. júl 1995, ked’ ju osobne navštívil pápež Ján Pavol II. O tomto slovanskom pápežovi je známe, že mal blízky vztah ku Slovensku, ktoré ako pápež navštívil až trikrát - v rokoch 1990, 1995 a 2003. Do programu jeho druhej návštevy bola zaradená aj Mariánska hora v Levoči. S výstavbou pápežského oltára sa začalo 8. mája 1995. Pápežský oltár bol 36 metrov dlhý, 30 metrov široký a 25 metrov vysoký. Na slávnostnú svätú omšu s Jánom Pavlom II. na Mariánskej hore prišlo okolo 650000 pútnikov, hoci bol pondelok 3. júla 1995 - pracovný deň. Medzi množstvom pútnikov boli aj veriaci z Pol’ska, Ukrajiny, Čiech, Mad’arska, Rumunska a iných krajín.

Okrem pápežskej návštevy iste prispeli k nárastu medzinárodného významu levočskej mariánskej baziliky aj návštevy takých osobností, ako sú napr. kardináli Jozef Tomko a Ján Chryzostom Korec (Slovensko), Karel Kašpar, Josef Beran a Miloslav Vlk (Česká republika), Zenon Grocholewski, Franciszek Macharski, Józef Glemp, Kazimierz Nycz, Stanisław Dziwisz a Stanisław Ryłko (Pol’sko), Christoph Schönborn (Rakúsko), Joachim Meisner, Rainer Maria Woelki, Georg Maximilian Sterzyński a Gerhard Ludwig Müller (Nemecko), Franc Rodé (Slovinsko), Angelo Sodano, Mauro Piacenza a Roberto Tucci (Taliansko), Jean Louis Pierr Tauran a Philippe Xavier Barbarin (Francúzsko), Antonio Augusto dos Santos Marto (Portugalsko) a d’alší (Dlugoš 2019, 33-244).

Ďalším dôležitým medzníkom v procese „globalizácie“ Mariánskej hory v Levoči bol 1. - 5. október 2005, ked’ bola zaradená do združenia European Marian Network, ktoré spája dvadsat' najvýznamnejších mariánskych svätýň starého kontinentu. S uvedeným faktom bezprostredne súvisí organizovanie v poradí 17. riadneho zasadania členov Európskej mariánskej siete, ktoré malo svoje dejinné miesto $\mathrm{v}$ Levoči $\mathrm{v}$ dňoch 17. - 20. septembra 2019. Nakolko obidvom spomenutým skutočnostiam budem venovat' osobitnú pozornost’ v tretej časti tohto článku, teraz sa nimi nebudem hlbšie zaoberat'.

K nárastu medzinárodného významu levočskej mariánskej baziliky iste prispel aj fakt, že 28. februára 2009 nadobudla duchovné spojenectvo s bazilikou Santa Maria Maggiore v Ríme, z čoho pre pútnikov plynú viaceré duchovné privilégiá - najmä možnost' získania odpustkov, ktoré sa pri splnení obvyklých podmienok dajú získat prakticky počas celého roka (na Výročie posviacky hlavnej mariánskej baziliky v Ríma 5. augusta, na sviatok Navštívenia preblahoslavenej Panny Márie 2. júla, na akúkolvek slávnost' Panny Márie, raz do roka podla lubovolného výberu jednotlivého veriaceho a kedykolvek sem príde skupina pútnikov prejavit’ náboženskú úctu).

Vtedajší levočský farár Mons. František Dlugoš požiadal 30. januára 2009 Apoštolskú penitenciáriu, aby bolo medzi levočskou a rímskou bazilikou vytvorené duchovné puto. Dekrét o nadobudnutí duchovného spojenectva mariánskej baziliky v Levoči s hlavnou mariánskou bazilikou v Ríme bol slávnostne prečítaný počas hlavnej púte na Mariánskej hore 5. júla 2009 
(Dlugoš - Štefaňak 2014, 55-61). Na okraj možno pripomenút', že bazilika Santa Maria Maggiore má okrem iného výnimočné miesto v najstarších dejinách Slovenska. Svätí Cyril a Metod predložili v roku 867 pápežovi Hadriánovi II. žiadost’ o povolenie slúžit sväté omše v staroslovienčine. Pápež súhlasil so zavedením štvrtého bohoslužobného jazyka a na znak súhlasu položil staroslovanské bohoslužobné knihy práve na oltár baziliky Santa Maria Maggiore (Škvarna et al. 2006, 20).

Medzi významné medzníky v procese „globalizácie“ Mariánskej hory v Levoči je potrebné pripočítat aj 7. jún 2013, ked’ bola zaradená do celosvetovej organizácie Worldpriest, ktorá okrem iného každoročne na slávnost’ Božského srdca Ježišovho spája najvýznamnejšie svätyne sveta $\mathrm{v}$ štafetovej modlitbe ruženca za posvätenie kňazov. V súčasnosti do tejto organizácie, ktorá vznikla v roku 2010, patrí viac ako tristo svätýň z rôznych krajín sveta. Worldpriest bolo založené skupinou laických veriacich, expertov v oblasti sociálnej komunikácie a médií, na podporu rôznych aspektov kňazskej služby. Jeho cielom je spájat kňazov a laikov, aby tak každý mohol prehĺbit svoj vztah s Ježišom Kristom a prežívat' Božiu prítomnost', lásku a ochranu. Zakladatel'kou a generálnou riaditelkou tohto združenia je Marion Mulhall z Írska (Worldpriest 2021).

Od spomínaného roku 2013 sa na Mariánskej hore každoročne na slávnost’ Božského srdca Ježišovho schádzajú biskupi, kňazi a množstvo veriacich laikov, aby sa v stanovenom čase (19.45) spoločne modlili stanovený ruženec za posvätenie kňazov, slávili svätú omšu a prijali eucharistické požehnanie - v spojení s veriacimi vo viac ako tristo svätyniach v rôznych krajinách sveta. Štafetová modlitba ruženca za posvätenie kňazov sa zvyčajne začína na slávnost’ Božského srdca Ježišovho o 0.00 (GMT) v ruskom Magadane na Sibíri, prechádza naprieč všetkými svetadielmi a končí v kanadskom Ontariu o 24.00 (GMT). Levočská bazilika spravidla „preberá ružencovú štafetu“ od španielskej Malagy a odovzdáva ju írskemu Knocku (Dlugoš 2019, 30-31).

Napokon k nárastu medzinárodnému významu levočskej mariánskej baziliky iste prispel aj fakt, že v roku 2016 bola zaradená do slovenskej sekcie Camino de Santiago. Trasa Svätojakubskej cesty na Slovensku vedie v smere východ - západ. Začína v Košiciach, pokračuje cez Levoču, Staré Hory, Hronský Beňadik, Nitru, Trnavu a končí v Bratislave. Celá trasa je dlhá približne $650 \mathrm{~km}$ a pešo zaberie približne 1 mesiac. Ďalej je možné pokračovat až do mesta Santiago de Compostela v španielskej Galícii. V Bratislave sa trasa napája na rakúsku Jakobsweg v mestečku Wolfstahl alebo na mad’arskú Szent Jakab út, ktorá prechádza dedinkou Rajka (Svätojakubská cesta na Slovensku 2021).

Jednotlivé časti Svätojakubskej cesty na Slovensku boli označované postupne. Jej prvá čast', ktorá sa začína v Košiciach a končí v Levoči, bola označená v roku 2016. Druhá čast', začínajúca v Levoči a končiaca na Starých Horách, bola označená v roku 2019. Tretia čast', ktorá sa začína na Starých Horách a končí v Hronskom Beňadiku, bola označená v roku 2017. Napokon štvrtá čast', začínajúca v Hronskom Beňadiku a končiaca v Trnave, ako aj piata čast', ktorá sa začína v Trnave a končí v Bratislave, boli označené v roku 2019 (Mróz - Mróz - Krogmann 2019, 66-67). Dokončením slovenskej sekcie Svätojakubskej cesty sa Slovensko a v rámci neho aj Mariánska hora v Levoči stali súčastou pútnickej cesty, ktorá má európsky rozmer a význam.

\section{Mariánska hora v Levoči v združení European Marian Network}

V tretej časti tohto článku by som chcel v krátkosti poukázat’ na miesto levočskej mariánskej baziliky medzi dvadsiatimi najvýznamnejšími mariánskymi svätyňami Európy. V tejto časti pôjde v značnej miere o informácie „Z prvej ruky“, nakolko som sa osobne zúčastnil na väčšine riadnych zasadaní členov združenia European Marian Network (v rokoch 2006 - 2016). Združenie

Európska mariánska siet’ spája dvadsat mariánskych svätýň starého kontinentu, čo symbolizuje 
dvadsat tajomstiev svätého ruženca. Sú doň zahrnuté najznámejšie a najvýznamnejšie mariánske pútnické miesta Európy. Panna Mária - Božia Matka - je v každej svätyni uctievaná pod iným titulom, ako aj rozdielnym spôsobom (http://www.ourladyofeurope.net/).

Združenie European Marian Network vzniklo na podnet pápeža Jána Pavla II. v roku 2003, v tom čase s počtom členov pätnást'. Ustanovujúce zasadanie sa uskutočnilo vo francúzskych Lurdoch. Na pozvanie tarbsko-lurdského diecézneho biskupa Mons. Jacquesa Perriera prišli na toto stretnutie zástupcovia nasledovných mariánskych svätýň Európy: Altötting (Nemecko), Banneux (Belgicko), Brezje (Slovinsko), Częstochowa (Pol’sko), Einsiedeln (Švajčiarsko), Fatima (Portugalsko), Knock (Írsko), Loreto (Taliansko), Lourdes (Francúzsko), Máriapócs (Madarsko), Mariazell (Rakúsko), Vilnius (Litva), Walsingham (Velká Británia), Zaragoza (Španielsko) a Zarvanyzia (Ukrajina) (Santos 2006, 4).

Druhé riadne zasadanie ešte vždy pätnástich členov sa uskutočnilo v roku $2004 \mathrm{v}$ portugalskej Fatime. Práve na tomto stretnutí sa rozhodlo, vzhladom na zvýšenie počtu tajomstiev svätého ruženca z pätnást’ na dvadsat', o zodpovedajúcom zvýšení počtu členov tohto združenia. Pät nových členov bolo prijatých na nasledujúcom riadnom zasadaní o rok neskôr. Išlo o nasledovné mariánske svätyne: Levoča (Slovensko), Csíksomlyó (Rumunsko), Marija Bistrica (Chorvátsko), Mellieha (Malta) a Gibraltár. Počnúc rokom 2005 sa teda zástupcovia levočskej mariánskej baziliky každoročne stretávajú so zástupcami d’alších devätnástich mariánskych svätýň Európy, aby sa navzájom lepšie poznali, delili so svojimi skúsenostami a lepšie pochopili nevypovedanú túžbu dnešného človeka po duchovných hodnotách. Prínos týchto stretnutí spočíva najmä v osobnej skúsenosti s dianím na jednotlivých pútnických miestach, ale aj v obohacujúcich prednáškach a diskusiách na vopred stanovené témy (Dlugoš - Štefaňak 2014, 75-76).

$\mathrm{V}$ poradí tretie riadne zasadanie, ktoré však bolo pre Mariánsku horu v Levoči prvé, sa uskutočnilo v mad’arskom meste Máriapócs. Konalo sa v dňoch 1. - 5. októbra 2005. Levočskú baziliku na stretnutí v Máriapócsi zastupovali Mons. František Dlugoš, rektor baziliky, a Mons. Ján Zentko, biskupský vikár Spišskej diecézy. Je potrebné podotknút, že samotné pozvanie na stretnutie členov Európskej mariánskej siete ešte neznamenalo aj prijatie do tohto významného združenia. Schvalovací proces pozostával z prezentácie levočskej baziliky - jej histórie a súčasnosti. Po predstavení nasledovalo tajné hlasovanie členov na čele s tarbsko-lurdským diecéznym biskupom Jacquesom Perrierom, ktoré rozhodlo o zaradení Baziliky Navštívenia Panny Márie na Mariánskej hore v Levoči do tohto združenia európskeho významu (Dlugoš 2008, 163-164).

Štvrté riadne zasadanie členov European Marian Network sa uskutočnilo v írskom meste Knock v dňoch 30. septembra - 4. októbra 2006. Program stretnutia sa niesol v duchu hlavnej myšlienky: Úloha pútnických miest v novej evanjelizácii. V poradí piate stretnutie sa uskutočnilo v litovskom hlavnom meste Vilnius v dňoch 17. - 21. septembra 2007. Jeho témou bolo: Božie milosrdenstvo $v$ centre sviatosti zmierenia. Šieste riadne zasadanie sa uskutočnilo v španielskom meste Zaragoza v dňoch 9. - 12. septembra 2008. Program stretnutia sa niesol v duchu hlavnej myšlienky: Mária, prameň živej vody (Štefaňak 2014, 58-68).

$\mathrm{V}$ poradí siedme stretnutie členov Európskej mariánskej siete sa uskutočnilo v polskej Częstochowej v dňoch 9. - 12. septembra 2009. Jeho témou boli: Duchovné skúsenosti pútnikov. Ôsme riadne zasadanie sa uskutočnilo v Gibraltári v dňoch 13. - 17. septembra 2010. Program stretnutia sa niesol v duchu hlavnej myšlienky: Naše Svätyne - miesta ekumenizmu a medzináboženských stretnutí. V poradí deviate stretnutie sa uskutočnilo v britskom Walsinghame $\mathrm{v}$ dňoch 27. - 30. septembra 2011. Jeho témou boli: Populárne znaky nábožnosti a evanjelizácie. Na okraj možno dodat', že zvláštnostou tohto stretnutia bola aktívna účast’ predstavitelov Anglikánskej cirkvi (Dlugoš - Štefaňak 2014, 99-116).

Jubilejné desiate riadne zasadanie členov European Marian Network sa uskutočnilo v Ríme v dňoch 18. - 21. septembra 2012. Toto stretnutie bolo výnimočné tým, že naň prijali pozvanie aj 
zástupcovia piatich mimoeurópskych najvýznamnejších mariánskych svätýň: Aparecida (Brazília), Guadalupe (Mexiko), Vailankanni (India), La Vang (Vietnam) a Kibeho (Rwanda). Hlavná myšlienka stretnutia v roku 2012 bola: Cesty, ktorými mariánske svätyne zaviedli do praxe usmernenia Druhého vatikánskeho koncilu. S osobitnou prednáškou vystúpil kardinál Antonio Maria Veglio, predseda Pápežskej rady pre pastoráciu migrantov a cestujúcich. Vo svojej prednáške okrem iného zdôraznil potrebu rozvíjat’ ludovú zbožnost', ktorá by mala privádzat’ veriacich k sláveniu a prijímaniu Eucharistie (Dlugoš - Štefaňak 2014, 117-122).

V poradí jedenáste stretnutie členov Európskej mariánskej siete sa uskutočnilo v Melliehe na Malte v dňoch 5. - 8. novembra 2013. Jeho témou boli: Pútnici a návštevníci na ceste do, va z mariánskej svätyne. Dvanáste riadne zasadanie sa uskutočnilo v Csíksomlyó v Rumunsku v dňoch 16. - 19. septembra 2014. Program stretnutia sa niesol v duchu hlavnej myšlienky: Mariánska cesta ako duchovná cesta pre pútnikov v strednej a východnej Európe (Štefaňak 2014, 82-86). V poradí trináste stretnutie sa uskutočnilo v Szentkút v Mad’arsku v dňoch 15. - 18. septembra 2015. Jeho témou bolo: Pokánie a odpustenie (Farské listy 2015, 20-21).

Štrnáste riadne zasadanie členov European Marian Network sa uskutočnilo v mestečku Zarvanytsya (Ukrajina) v dňoch 19. - 22. septembra 2016. Program stretnutia sa niesol v duchu hlavnej myšlienky: Božia Matka - „brána milosrdenstva“ pre každého veriaceho (Farské listy 2016, 25-26). V poradí pätnáste stretnutie sa uskutočnilo vo Fatime (Portugalsko) v dňoch 26. - 29. septembra 2017. Jeho témou bolo: 100. výročie fatimských zjavení (Farské listy 2017, 24-25). Šestnáste riadne zasadanie sa uskutočnilo v mestečku Brezje (Slovinsko) v dňoch 25. - 28. septembra 2018. Program stretnutia sa niesol v duchu hlavnej myšlienky: Miesto svätyne v živote Cirkvi (Farské listy 2018, 19-21).

Doposial' posledné - sedemnáste riadne zasadanie členov Európskej mariánskej siete sa uskutočnilo v slovenskej Levoči (pretože v roku 2020 sa stretnutie neuskutočnilo $\mathrm{z}$ dôvodu pandémie COVID-19). Konalo sa v dňoch 17. - 20. septembra 2019. Program stretnutia sa niesol v duchu hlavnej myšlienky: Mária - aktuálny prorotyp krestana. Hlavnú prednášku predniesol olomoucký arcibiskup Jan Graubner, ktorý podčiarkol, že Panna Mária je učitelkou viery, vzorom služby, budovatelkou Cirkvi, matkou i královnou veriacich. Okrem toho pripomenul, že medzi novými formami evanjelizácie by nemali chýbat púte a iné duchovné podujatia pre rôzne profesijné skupiny. Delegáti dvadsiatich najvýznamnejších mariánskych svätýň starého kontinentu navštívili - okrem baziliky na Mariánskej hore - aj baziliku svätého Jakuba v Levoči, katedrálu svätého Martina v Spišskej Kapitule a kostol Svätého Ducha v Žehre (Farské listy 2019, 20-25).

Združenie European Marian Network spočiatku fungovalo pod predsedníctvom tarbsko-lurdského diecézneho biskupa Mons. Jacquesa Perriera (v rokoch 2003 - 2012), ktorý mu spolu so svojím tímom venoval zvláštnu pozornost'. Okrem iného si kládol za povinnost̉ osobne navštívit všetky členské svätyne v deň ich výročnej slávnosti. V tomto duchu sa napr. zúčastnil hlavnej púte na Mariánskej hore v Levoči v dňoch 7. - 8. júla 2007 (Santos 2011, 4). Po skončení jeho služby v pozícii tarbsko-lurdského diecézneho biskupa opisované združenie funguje na spôsob „štafetového predsedníctva“. To znamená, že mu predsedá vždy rektor tej svätyne, ktorá pripravuje najbližšie riadne zasadnutie. V načrtnutom kontexte mu napr. v rokoch 2012 - 2013 predsedal rektor svätyne v maltskej Mielliehe, v rokoch 2018 - 2019 rektor svätyne v slovenskej Levoči a momentálne už druhý rok rektor svätyne vo švajčiarskom Einsiedelne.

Opisované združenie v prvom desatročí svojho fungovania vydalo dve oficiálne publikácie (bulletiny) v šiestich jazykoch (francúzsky, taliansky, španielsky, anglicky, nemecky a holandsky). Prvá so základnými informáciami o združení, ako aj o každej z dvadsiatich európskych mariánskych svätýň bola publikovaná v roku 2006 (Santos 2006). Druhá rozšírená o informácie a typické modlitby v jednotlivých svätyniach v ich vlastných jazykoch bola publikovaná v roku 2011 (Santos 2011). Okrem toho býva bežnou praxou, že v areáloch dotknutých svätýň sa nachádzajú 
informačné panely o Európskej mariánskej sieti a podobne aj na ich webových stránkach. Týmto spôsobom návštevník ktorejkolvek z dvadsiatich mariánskych svätýň starého kontinentu alebo jej webovej stránky dostáva základné informácie aj o ostatných devätnástich, čo je pre ne velmi výhodné a dôležité.

\section{Záver}

Na zakončenie predstavenia dávnejšej - lokálnej, ale najmä novšej - globálnej histórie Mariánskej hory v Levoči je potrebné povedat', že jej náboženský a kultúrny význam neustále narastá: a to nielen v rámci Slovenska, ale aj v rámci Európy a sveta. Osobitným spôsobom je potrebné zdôraznit, že pätnástročná aktívna prítomnost̉ zástupcov levočskej mariánskej baziliky na riadnych zasadaniach členov European Marian Network bola, je a bude dôležitá nielen pre Mariánsku horu $\mathrm{v}$ Levoči, ale aj pre celé Slovensko. Aj vd’aka tomu sa o Levoči v Európe i vo svete vie. V tomto kontexte iste nie je bezvýznamné, že v Lurdoch, Fatime alebo Knocku vidíme okrem iného aj obraz alebo panel s levočskou Pannou Máriou, prípadne krátku informáciu o levočskej mariánskej svätyni.

Podobne platí, že aj vdaka tomu Mariánsku horu v Levoči z vlastnej iniciatívy navštívili také osobnosti, ako napr. tarbsko-lurdský diecézny biskup Jacques Perrier počas hlavnej púte v roku 2007 alebo diecézny biskup v Leiria-Fatima Antonio Marto počas hlavnej púte v roku 2008. Okrem toho, ako som vyššie zdokumentoval, v roku 2019 navštívili Mariánsku horu v Levoči zástupcovia všetkých dvadsiatich najvýznamnejších mariánskych svätýň Európy - pri príležitosti 35. výročia vyhlásenia svätyne na Mariánskej hore za baziliku menšiu a 10. výročia jej duchovného spojenia s bazilikou väčšou Santa Maria Maggiore v Ríme. Vzhladom na uvedené i neuvedené dejinné fakty možno bez nejakej nezdravej hrdosti povedat', že Mariánsku horu v Levoči si ludia na Slovensku, v Európe i vo svete vážia ako významné duchovné a kultúrne dedičstvo.

\section{REFERENCES}

Dlugoš, František. 2008. Mariánska Levoča a jej osobnosti medzi svätyňami Európy. Levoča. Dlugoš, František. 2013. Mariánska hora v Levoči. 1247 - 2013. Levoča.

Dlugoš, František. 2015. Štefan Garaj si zachoval tvár a vieru. Sto rokov od narodenia kapitulného vikára Spišskej diecézy. Levoča.

Dlugoš, František. 2019. Vzdávali úctu levočskej Panne Márii. Sv. Ján Pavol II a kardináli. Levoča. Dlugoš, František - Štefaňak, Ondrej. 2014. Levočská bazilika - kompas i maják viery. Levoča.

Farské listy. 2015. Farské listy 2015. Časopis farského úradu v Levoči. Levoča. Farské listy. 2016. Farské listy 2016. Časopis farského úradu v Levoči. Levoča. Farské listy. 2017. Farské listy 2017. Časopis farského úradu v Levoči. Levoča. Farské listy. 2018. Farské listy 2018. Časopis farského úradu v Levoči. Levoča. Farské listy. 2019. Farské listy 2019. Časopis farského úradu v Levoči. Levoča.

Chalupecký, Ivan. 2006. Mariánska hora v Levoči. Člen Európskeho združenia mariánskych pútnických miest. Trnava.

Jurik, Rudolf. 1948. Mariánska hora v Levoči. Levoča.

Klubert, Štefan. 1970. Pútnická Levoča. In Pútnik svätovojtešský. Kalendár Spolku sv. Vojtecha. Trnava, 105-107.

Kompanyik, Celestín. 1891. Sz. Jakab templom története. Levoča.

Kosová, Katarína (ed.). 2016. Národné kultúrne pamiatky na Slovensku - Levoča. Bratislava. 
Mróz, Franciszek - Mróz, Łukasz - Krogmann, Alfred. 2019. Factors Conditioning the Creation and Development of a Network of Camino de Santiago Routes in Visegrád Group Countries. In International Journal of Religious Tourism and Pilgimage 7/5, 55-71.

Our Lady of Europe. 2021. Our Lady of Europe. http://www.ourladyofeurope.net/.

Santos, Pascale. 2006. Lé Réseau Marial Européen. Lourdes.

Santos, Pascale. 2011. Lé Réseau Marial Européen. Lourdes.

Sugier-Szerega, Anna. 2004. Sanktuarium. In Libiszowska-Żółtkowska, Maria - Mariański, Janusz (ed.). Leksykon socjologii religii. Warszawa, 360-361.

Svätojakubská cesta na Slovensku. 2021. Svätojakubská cesta na Slovensku. Camino de Santiago. https://www.caminodesantiago.sk/.

Škvarna, Dušan et al. 2006. Lexikón slovenských dejín. Bratislava.

Štefaňak, Ondrej. 2014. Levočská bazilika a výročné konferencie Európskej mariánskej siete. In Dlugoš, František (ed.). Regnum Marianum - ozdoba a istota Slovenska. Levoča, 53-86.

Worldpriest. 2021. Worldpriest. https://www.worldpriest.com/.

doc. PhDr. Ondrej Štefaňak, PhD.

Constantine the Philosopher University in Nitra

Faculty of Arts

Department of Sociology

B. Slančíkovej 1

94974 Nitra

Slovakia

ostefanak@ukf.sk

ORCID ID: 0000-0001-9362-993X

WOS Researcher ID: AAG-6800-2020 